\title{
A Tale of Two Neighbourhoods: Some Evidence of Leadership, Learning, and Liveability
}

\author{
Nurussaadah Mokhtar* and Melasutra Md. Dali \\ Centre for Sustainable Urban Planning and Real Estate (SUPRE), Faculty of Built \\ Environment, University of Malaya, 50603, Kuala Lumpur. \\ *nurussaadahmokhtar@gmail.com
}

Research on community-based organisations' potentials and capacities to mobilise community at grassroots levels are emerging rapidly. Yet, inadequacy in terms of understanding how these grassroots institutions participate within Local Agenda 21 processes persists. Despite the establishment of Local Agenda 21 for sixteen years in Malaysia, research on the development of community leadership and learning in mobilising community remains scarce. This paper thus attempts to assess community leadership and learning through participation in Local Agenda 21 programs. Triangulated data collection methods comprising document analysis, experts' interviews, and case study approach were undertaken to evaluate the development of local sustainable initiatives implemented by two community-based organisations within the platform of community participation facilitated by the City Council of Petaling Jaya. Building on Purdue's leadership and trust framework as well as instrumental and communicative learning concepts, this qualitative study finds that continuous participation resulting from a continuous charismatic leadership has caused the local neighbourhoods to keep learning. This finding suggests that neighbourhoods participating actively in sustainability platform may substantially contribute to social dimensions of neighbourhood liveability, depending on the extent of community leadership and learning.

Keywords: community leadership and learning, community-based organizations, neighbourhood liveability, Local Agenda 21, community participation, and sustainable initiatives

\section{INTRODUCTION}

Local Agenda 21 (LA21) traces its origin back to the United Nations Conference on Environment and Development (UNCED) or more popularly known as the Earth Summit, held in Rio de Janeiro, Brazil in 1992. The conference produced an action plan called Agenda 21 to denote the strategies for the $21^{\text {st }}$ century. It aims at achieving the goals of Sustainable Development. While the central and the state governments play significant roles in broader policy-making processes, the level of local government under LA21 has been given a role in mobilising grassroots communities apart from performing their major role in service delivery. Community-based organisations (CBOs) are regarded as one of the stakeholders, along with state and the federal government agencies, NGOs, and private sectors within a 'space' created under LA21 (Pereira et al., 2005). In 2015, a set of renewed goals originated from the Agenda 21 known as Sustainable Development Goals outlined sustainable cities and communities as one of its main goals. This stems from the awareness that critical issues and challenges in sustainability are mostly found in urban areas. Statistics provided by the United Nations (UN) show that the percentage of Malaysian urban population in 2015 is at 73 per cent. This figure is growing at the rate of 2.7 per cent annually. By the year 2020 , it is expected that local authorities in urban areas will face more complex challenges. In the age of governance, the local authorities are not the only parties responsible as the community performs complementary functions and holds partial responsibility in the environment where they live in.

Although a great deal of literature on LA21 in Malaysia has focused on approaches to its implementation by local authorities, little work has addressed the roles played by CBOs in partnership arrangements and community participation approaches within the platform of LA21. Existing research on CBOs in the country is limited within the context of community development programs, although their roles as stakeholders in local governance partnership are well-recognised. Nonetheless, studies on CBOs' potentials and capacities to 
mobilise community at grassroots levels (Bradbury \& Middlemiss, 2015; Hoe et al., 2015; Middlemiss, 2011; Krishna, 2003) are emerging rapidly. Yet, the inadequacy in understanding of how these grassroots institutions participate within LA21 processes is still substantial.

A study by Munro et al. (2006) acknowledged both community leaders and public managers as 'dual intermediaries' in the democratic arena of partnership working. However, investigations on the roles of CBO leadership in the literature of LA21 are scarce. The earliest work is traced by Mehta (1996) who stated that without CBOs leadership, LA21 processes will be slow and lack momentum. This view was supported by Selman and Parker (1997) who concluded that community leadership is an important sustainability strategy in forging the relationship between the local government and the local community. For almost two decades, with exceptions of Mehta (1996) and Selman and Parker (1997), almost no studies on LA21 have emerged within the field of community leadership.

A preliminary study has shown that the implementation of LA21 in Petaling Jaya within the span of fifteen years has generated learning communities under strong and charismatic leaderships (Mokhtar \& M.Dali, 2015). While such research explores some relationship between community participation, leadership, and learning, a deeper investigation into their relationship with liveability may contribute better to the understanding of CBOs' roles in partnership and participation arrangements. Hence, this research seeks to fill this gap, namely by evaluating how leadership and learning within CBOs affect their communities' liveability.

\section{LOCAL AGENDA 21 IN PETALING JAYA}

Petaling Jaya had an opportunity to engage in the pursuit of sustainable development when its city council became among the four selected local authorities out of 145 local authorities nationwide to implement the first round of Local Agenda 21 in Malaysia (Mokhtar \& M.Dali, 2015). In 2003, the Ministry of Housing and Local Government (MHLG) published LA21 Guide and Case Studies which acknowledged the best practices of partnership and participation by the City Council of Petaling Jaya or Majlis Bandaraya Petaling Jaya (MBPJ) in LA21 to serve as guidelines for other local authorities. As of today, MBPJ has been regarded as a leading local authority in LA21 implementation in Malaysia (Yuen et al., 2006).

The milestone of LA21 implementation in MBPJ can be divided into three time periods: firstly, from the period of its inception (2000) until 2008, secondly, from 2008 until 2013, and finally, from 2013 until today (refer to Figure 1). These distinctions are made since the brand name of LA21 has been used by MBPJ from the beginning of its instalment until it was rebranded or replaced with 'Liveable City' in the year 2008 and 'Sustainable PJ 2030' in 2013. Liveable City became MBPJ's vision until the Strategic Plan for sustainability was launched in 2013. Both LA21 and Liveable City were brand names employed by MBPJ in the pursuit of sustainability. Within sixteen years of LA21's implementation, three major consultations have been conducted with the local communities. The first was held in 2000 as part of the required process in LA21 Action Planning. The consultation produced three action plans which became the foundation for the start of the partnership and participation in LA21 in MBPJ. Six years after the pilot project ended, the second major consultation called the 'Liveable City' Workshop was held. The outcome of the workshop was eight action plans and a Citizens' Documentation. Finally, as part of the LA21 evaluation exercise, the third major consultation was held in 2015 with the purpose of getting local communities' feedback on the progress of LA21. It resulted in the rebranding of MBPJ's LA21 to PJKita (translated as 'Our Petaling Jaya'). All three major consultations are significant points of LA21 progress as LA21 pathways were renewed by MBPJ. 


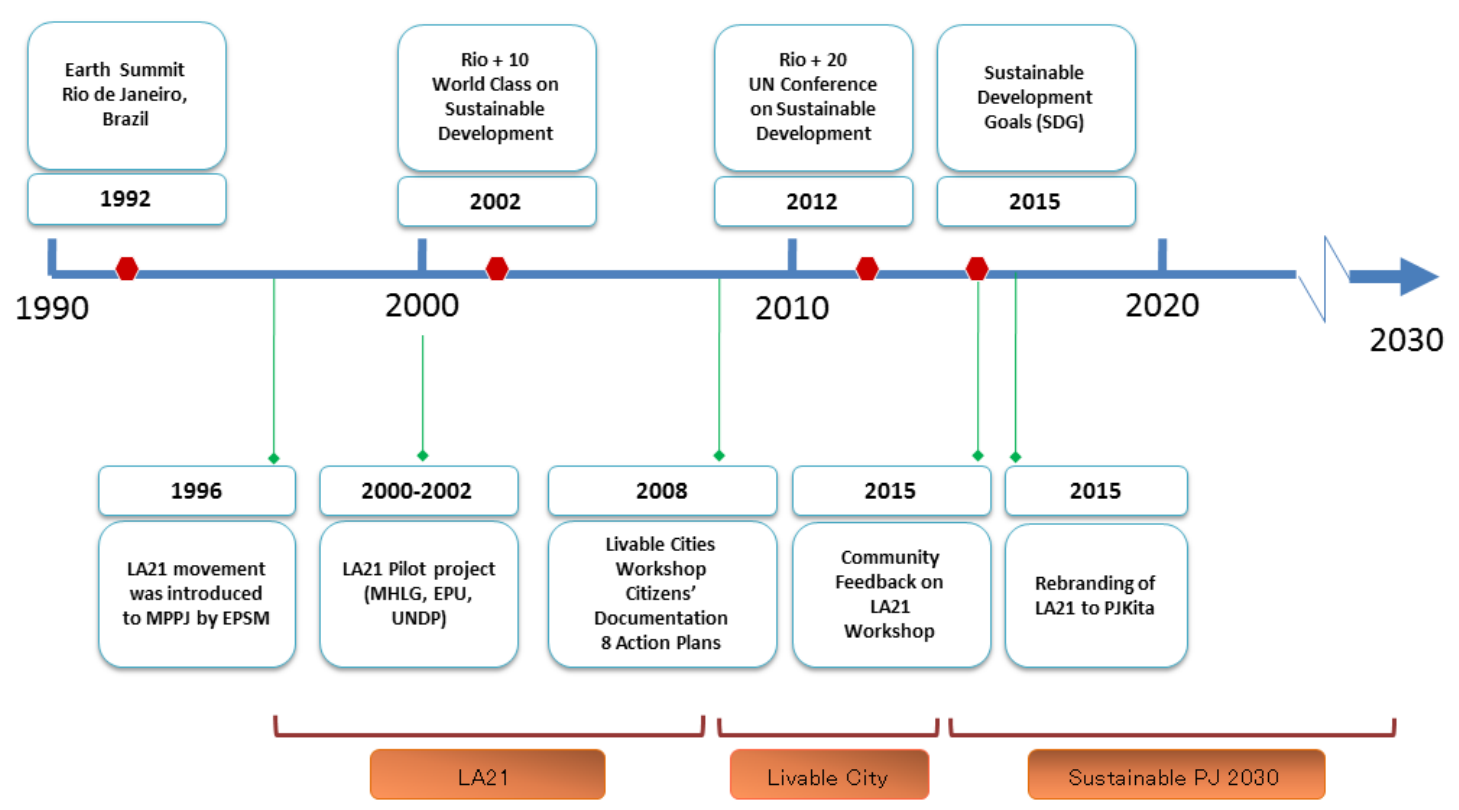

Figure 1: The timeline of LA21 implementation by MBPJ

Source: Multiple documents obtained by MBPJ (2015)

\section{LITERATURE REVIEW}

\subsection{Potentials and capacities of local communities in participation}

While proponents of democratic citizen participation view the size of participation as an essential indicator of successful participation, Brandt and Svendsen (2013) on the contrary concluded that the cost of consensus building is likely to exceed the benefits, particularly when the number of participants is higher. Their quantitative analysis findings suggest that small local communities may solve sustainability problems better, where the quality of decision is enhanced. Likewise, community governance workshops as part of the South African West Coast development planning process recorded similar observations. Groenewald and Smith (2002) claimed that the process was timeconsuming and questioned its cost effectiveness and potential to deliver. In the same vein, Irvin and Stansbury (2004) highlighted the disadvantages of citizen participation, claiming that it is costly and therefore, ineffective. Small, committed, and accountable stakeholders (Roberts \& Diedriechs, 2002) such as CBOs therefore pose an advantage for more effective community participation.

An examination of an American neighbourhood revitalisation program as reported by Fagotto and Fung (2006) provided evidence of meaningful and innovative modes of participation. Unlike conventional practices of participation as reported by Häikiö (2012), the revitalisation program provides opportunities for residents to participate in such urban governance initiative at their own neighbourhood level (Fagotto \& Fung, 2006). Furthermore, the participation measure is not limited to face-to-face deliberation process alone, but includes multiple modes of participation such as surveys, door-to-door canvassing, meetings, and focus groups. While a huge amount of studies on community participation concentrated on the desired outcomes of participation (Häikiö, 2012), the study by Fagotto and Fung (2006) went beyond the common perspective of participation. Effective community participation in their viewpoint is the one taking place at its own localities, managed by neighbourhood organisations, as they provide power and resources for them to mobilise. This is echoed by Selman and Parker (1997) who initiated a study linking LA21 to social capital by claiming that citizen participation requires a 'place' to be nurtured in. By 'place', they were referring to local neighbourhoods where bonds of trust are built. As CBOs govern a specific neighbourhood area, they possess greater potentials for cultivating effective community participation despite being small in size. 


\subsection{Leadership, trust and participation in LA21}

In Malaysia, other than the in-depth interviews with eight Chairmen of neighbourhood associations in Malaysia which concluded the effectiveness of participative leadership (Mohamad et al., 2009), studies on community leadership remain scanty. However, studies on community trust in local governments have emerged. While Nordin et al. (2012) identified trust as a necessary ingredient for community engagement and participatory processes in a case study involving Subang Jaya Municipal Council, Md Zan and Ngah (2012) found that the perception of local communities towards local councillors in Seberang Prai affected their participation in LA21 initiatives. A more recent finding on trust identified the relationship between time and trust building; Bos and Brown (2015) discovered that extended community engagement process is an opportunity to build trust, which in turn leads to greater community participation. Apart from trust in local governments, Md Zan et al. (2014) recognised public trust and confidence in their local community leaders as a contributing factor of LA21 participation.

Community participation and community leadership require nurturing and resourcing as they involve largely unpaid resources from citizens (Selman \& Parker, 1997). Although this indirectly recognises the relationship between leadership and trust as well as the time taken to achieve them, these two elements of social capital have been treated separately by scholars, until Purdue (2001) provided an imperative examination of their relationship in the context of neighbourhood governance level. Purdue (2001) differentiated qualities of two types of leaders, namely 'transactional leaders' and 'transformational leaders'. Based on his indepth qualitative analysis, he concluded that a "transformational leader" possesses the ability to build and accumulate 'collaborative trust', while a 'transactional leader' who successfully connects with the community is regarded as being effectively building what he called the 'communal trust'. Both transactional and transformational leaders, based on his observations, fit the image of charismatic leaders: visionary, possessing sense of vocation, quick to spot opportunities, able to turn contingencies into advantages, work with the available conditions, and collaborate well (Purdue, 2001).

\subsection{Community learning through participation in sustainability efforts}

While LA21 processes result in the accumulation of social capital stemming from leadership and trust as elaborated previously, learning among the community takes place too (Barrutia \& Echebarria, 2011). As opposed to proponents of democratic citizen participation, Michels and De Graaf (2010) claimed that the most important aspect of citizen participation is not to have a say in the decision-making but more on the education and development of civic skills. In particular, Andrews et al. (2008), through a multi-methods study of English local authorities, emphasised the role of citizen participation in engaging, educating, and empowering local citizens. Similarly, Novy and Hammer (2007) argued that participation exercises empower local actors, while Ottozimmermann (2012) specified LA21 as a key platform for disseminating knowledge and information among participating actors. These are among the considerable amounts of work which have elaborated on community learning as a result of participation in sustainability efforts. In addition, a more specific type of skills learning was identified by Peris et al. (2011) who asserted that through participatory processes, communities spend time on developing their communication skills. Communication and interaction of different actors in a participatory setting are believed to result in a set of social outcomes such as the generation of new knowledge, the acquisition of technical and social skills, as well as the development of trust and relationships (Muro \& Jeffrey, 2008). An element of time is significant in understanding community participation and learning as participation is regarded as a process while learning requires time. This is evident through the observation made by Brooks and Moore (1997) where a learning community is recognised as a specific community for which learning is continuous and transforming.

Participatory processes require communities to be involved in learning. As observed by Abdul Halim et al. (2011) in a case study conducted in Langkawi, active local participation in resource management allows members of community to learn about natural resources and leads to concrete actions on the ground towards achieving sustainable solutions. Table 1 categorises different researchers' observations on the two types of learning acquired from various participatory approaches. Instrumental learning is defined as learning to 
manipulate or control the environment or other people to enhance efficacy in improving performance, while communicative learning involves at least two persons striving to reach an understanding of the meaning of an interpretation or the justification for a belief (Mezirow, 1997). The works of Sims (2012), Spaling et al. (2011), Marschke and Sinclair (2009), and Kilpatrick et al. (1999) identified two types of instrumental learning skills, namely administrative and technical skills. Specifically, the administrative skills acquired include learning skills to adopt best management practices as well as skills in decision-making and leadership (Kilpatrick et al., 1999), learning about community-based strategic environmental assessment and its role in programme planning, developing problemsolving skills, and effective group-work strategies (Sims, 2012). On the contrary, communicative learning has been observed in a number of studies, namely on the knowledge of how to work together and how to work with various levels of government (Kilpatrick et al., 1999), changes in behaviour at the community level through insights into the need to conserve mangroves (Marschke \& Sinclair, 2009), shared values of environmental sustainability and community unity (Spaling et al., 2011), efforts to become more self-aware and appreciative towards environmental conservation and collaboration (Sims, 2012).

Table 1: Types of learning acquired through various participatory processes

\begin{tabular}{lll}
\hline Author(s) & Instrumental learning & Communicative learning \\
\hline Kilpatrick et al., 1999) & $\begin{array}{l}\text { Learning to adopt best } \\
\text { management practices and skills } \\
\text { in decision-making, leadership, } \\
\text { technical knowledge }\end{array}$ & $\begin{array}{l}\text { Learning how to work together, } \\
\text { learning how to work with various } \\
\text { levels of government }\end{array}$ \\
\hline (Marschke \& Sinclair, & $\begin{array}{l}\text { Learning about administrative } \\
\text { procedures }\end{array}$ & $\begin{array}{l}\text { Changes in behaviour at the } \\
\text { community level }\end{array}$ \\
\hline (Spaling et al., 2011) & $\begin{array}{l}\text { Technical skills for erosion } \\
\text { control }\end{array}$ & $\begin{array}{l}\text { Shared values of environmental } \\
\text { sustainability and community } \\
\text { unity }\end{array}$ \\
& $\begin{array}{l}\text { New information about } \\
\text { environmental assessment }\end{array}$ & $\begin{array}{l}\text { Learning about community-based } \\
\text { strategic environmental } \\
\text { assessment and its role in } \\
\text { programme planning, developing } \\
\text { problem solving skills, effective } \\
\text { group-working strategies, and } \\
\text { technical information }\end{array}$ \\
\hline (Sims, 2012) & conservation and collaboration \\
&
\end{tabular}

\subsection{Indicators of a neighbourhood's liveability}

There seems to be an abundance of research that explores liveability. While there is a wide range of indicators for measuring liveability, a neighbourhood's liveability may be summarised in five broad categories, as shown in Table 2. Callahan (2007) and Howley et al. (2009) defined a community's liveability based on its civic-mindedness. Callahan (2007) mentioned that a community's active participation signals its wellbeing, while its absence or lack of participation lead to community dissatisfaction (Howley et al., 2009). Social cohesion, however, appears to be a more weighty definition of a neighbourhood's liveability (Balsas, 2004; Buys \& Miller, 2012; Dola \& Mohd Noor, 2012; Lloyd, Fullagar, \& Reid,
2016; Throsby, 2005; Wheeler, 2001). For a neighbourhood to function as an effective public space, it has to be characterized by a healthy social interaction (Razavizadeh et al., 2016), which leads towards social cohesion. The third broad category identifies local activities taking place in a neighbourhood as a distinct liveability indicator (Balsas, 2004; Throsby, 2005; Wheeler, 2001). While liveability indicators such as civic-mindedness, social cohesion, and local activities fit the framework of social dimension, the other two categories of indicators, namely neighbourhood management (Balsas, 2004; Leby \& Hashim, 2010) and networking (Leby \& Hashim, 2010; Throsby, 2005) appear to fit the framework of functional environment dimension of liveability (Leby \& Hashim, 2010). 
Table 2: A neighbourhood's liveability indicators

\begin{tabular}{|c|c|c|}
\hline Aspects & Characteristics of liveability & Author(s) \\
\hline \multirow{2}{*}{$\begin{array}{l}\text { Civic- } \\
\text { mindedness }\end{array}$} & $\begin{array}{l}\text { Citizen engagements, community participation, } \\
\text { stronger sense of inclusion }\end{array}$ & (Callahan, 2007) \\
\hline & Community involvement & (Howley et al., 2009) \\
\hline \multirow{7}{*}{ Social cohesion } & Social interaction and social cohesion & (Lloyd et al., 2016) \\
\hline & $\begin{array}{l}\text { Social contacts (family, friends, and familiar faces) } \\
\text { in the neighbourhood }\end{array}$ & (Buys \& Miller, 2012) \\
\hline & Sense of community & (Balsas, 2004) \\
\hline & $\begin{array}{l}\text { Environment that nurtures human community and } \\
\text { interaction }\end{array}$ & (Wheeler, 2001) \\
\hline & $\begin{array}{l}\text { Elements of community life and social contact- } \\
\text { friends, moral support, relationships with } \\
\text { neighbours }\end{array}$ & (Leby \& Hashim, 2010) \\
\hline & Strong attachment and sense of belonging & (Dola \& Mohd Noor, 2012) \\
\hline & Sense of place & (Throsby, 2005) \\
\hline \multirow{3}{*}{ Local activities } & Distinctive local activity & (Throsby, 2005) \\
\hline & Interesting cultural activities & (Balsas, 2004) \\
\hline & Places that emphasise local culture & (Wheeler, 2001) \\
\hline \multirow{2}{*}{$\begin{array}{l}\text { Neighbourhood } \\
\text { management }\end{array}$} & Efficient administration & (Balsas, 2004) \\
\hline & Maintenance of environment & (Leby \& Hashim, 2010) \\
\hline \multirow{3}{*}{ Networking } & Source of liaisons & (Leby \& Hashim, 2010) \\
\hline & Source of economic and bases for life & (Leby \& Hashim, 2010) \\
\hline & Well-established social networks & (Throsby, 2005) \\
\hline
\end{tabular}

\section{METHODOLOGY}

\subsection{Data collection methods}

A set of triangulated data collection methods comprising the case study approach, document analyses, and experts' interviews was undertaken in this study.

\subsection{Document analysis}

Most secondary data were acquired with permission from MBPJ, where researchers arranged regular visits to the Department of City Planning and Sustainable Development. As shown in Table 3, the documents and records produced or stored by MBPJ are mostly unpublished and unavailable to the public. In addition, there were other information in other formats such as blog reports, community newsletters, and brochures which were either acquired from online searches or shared by interviewees.

Table 3: Sources and contents of multiple types of documents and records

\begin{tabular}{|l|l|l|}
\hline $\begin{array}{l}\text { Sources of } \\
\text { secondary } \\
\text { data }\end{array}$ & Type of Data & Description of contents \\
\hline Documentation & Communiqués & Chains of e-mail between MBPJ and engaged experts \\
\cline { 2 - 3 } & $\begin{array}{l}\text { Written reports of } \\
\text { events }\end{array}$ & $\begin{array}{l}\text { Reports of Sustainable Community Award (SCA) by the head } \\
\text { of engaged experts } \\
\text { Minutes of SCA -related meetings } \\
\text { Budget proposals }\end{array}$ \\
\hline \multirow{2}{*}{$\begin{array}{l}\text { Archival } \\
\text { records }\end{array}$} & Policy statements & Sustainable PJ Strategic Plan 2030 \\
\cline { 2 - 3 } & $\begin{array}{l}\text { Onnual records } \\
\text { records }\end{array}$ & $\begin{array}{l}\text { Record of SCA award receivers, the participation of all } \\
\text { events under APKM and LA21 held by MBPJ }\end{array}$ \\
\cline { 2 - 3 } & $\begin{array}{l}\text { Maps and } \\
\text { geographical } \\
\text { charts }\end{array}$ & $\begin{array}{l}\text { Organisational structures of MBPJ, the Planning Department, } \\
\text { and Committee specifically for Sustainable PJ }\end{array}$ \\
\hline & $\begin{array}{l}\text { Maps of PJ including land uses, Council members' zones of } \\
\text { jurisdiction, State Assemblymen, and MP jurisdiction areas }\end{array}$ \\
\hline & \multicolumn{2}{|l}{ List of engaged experts, a list of CBOs, a list of attendees of } \\
\hline
\end{tabular}




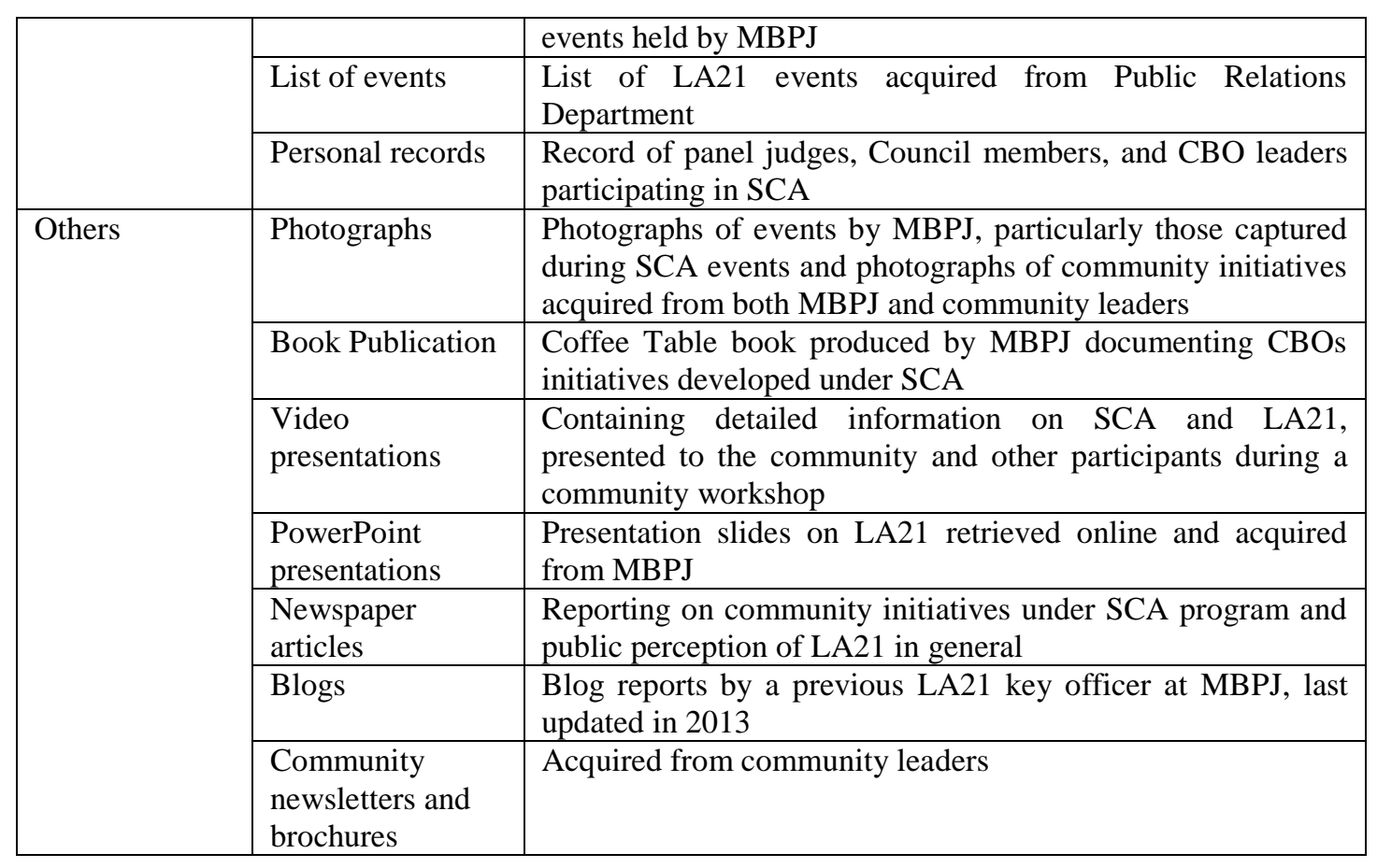

\subsection{Experts' interviews}

The selection of four key experts was guided by the principle of a type of purposive sampling called the expert sampling. They include MBPJ staff and professionals from diverse backgrounds who have worked with MBPJ voluntarily. The professionals have volunteered in partnership with MBPJ for sixteen years and therefore are highly experienced with CBOs' participation in sustainable initiatives under a major LA21 program known as Sustainable Community Award (SCA). Weiss (1995) described two distinct categories of potential respondents for qualitative interviews: first, people who are uniquely able to be informative because they are experts in an area or were privileged to witnesses an event, and second, people who, taken together, displayed what has happened within a population affected by a situation or event. The number of experts identified and available for the face-to-face interview was four. As suggested in Weiss' (1995) recommendation, the four experts were selected as they have been permanent external experts engaged by MBPJ to evaluate the progress of CBOs which participated in the SCA. Their knowledge and experience in collaborating with MBPJ and in monitoring the progress of local sustainable community initiatives spanned sixteen years. Serving on a basis of volunteerism with MBPJ and the local communities, these experts are professionals in environmental sustainability from various sectors of government agencies, academia, private companies, and non-governmental organisations.

Table 4: Details of informants selected for expert interview.

\begin{tabular}{|l|l|l|}
\hline \multicolumn{2}{|c|}{ Group of experts } & \multicolumn{1}{c|}{ Background } \\
\hline \multirow{4}{*}{$\begin{array}{l}\text { External } \\
\text { experts }\end{array}$} & E-E1 & $\begin{array}{l}\text { LA21 Project Officer (2000-2002) at KPKT/ LA21 Consultant. } \\
\text { An architect by profession. }\end{array}$ \\
\cline { 2 - 3 } & E-E2 & $\begin{array}{l}\text { Council member at Environmental Management and Research Association of } \\
\text { Malaysia (ENSEARCH). }\end{array}$ \\
\cline { 2 - 3 } & E-E3 & Coordinator of River Care Programme, Global Environment Centre (GEC). \\
\hline MBPJ officer & M-E1 & $\begin{array}{l}\text { The former head of LA21 Unit, MBPJ. Currently the Head of Solid Waste } \\
\text { Management Department at MBPJ. }\end{array}$ \\
\hline
\end{tabular}

\subsection{Case study approach}

Two well-recognised CBOs are selected as case studies to assess how leadership and learning has contributed to their community's liveability. Both CBOs have been selected due to their reputation as exemplary neighbourhood. An annually implemented program since the year 
2001 until today requires participating CBOs to actively engage and mobilise local communities in sustainable initiatives.
Table 5 shows that $\mathrm{R} 1$ and $\mathrm{R} 10$ have been recognized continuously for their high achievements as sustainable community in comparison to other participating CBOs.

Table 5: Participation of RAs in LA21 major program

\begin{tabular}{|c|c|c|c|c|c|c|c|c|c|c|c|}
\hline & \multicolumn{11}{|c|}{ Year } \\
\hline CBOs & '04/ & '05/ & '06/ & '07/ & '08/ & '09/ & '10/ & '11/ & '12/ & '13/ & '15/ \\
\hline & ‘05 & ‘06 & ‘07 & '08 & ‘09 & ‘10 & '11 & '12 & '13 & '14 & '16 \\
\hline \multicolumn{12}{|l|}{ R1 } \\
\hline \multicolumn{12}{|l|}{$\mathrm{R} 2$} \\
\hline \multicolumn{12}{|l|}{ R3 } \\
\hline \multicolumn{12}{|l|}{ R4 } \\
\hline \multicolumn{12}{|l|}{ R5 } \\
\hline \multicolumn{12}{|l|}{ R6 } \\
\hline \multicolumn{12}{|l|}{ R7 } \\
\hline \multicolumn{12}{|l|}{$\mathrm{R} 8$} \\
\hline \multicolumn{12}{|l|}{ R9 } \\
\hline \multicolumn{12}{|l|}{ R10 } \\
\hline \multicolumn{12}{|l|}{ R11 } \\
\hline \multicolumn{12}{|l|}{ R12 } \\
\hline \multicolumn{12}{|l|}{ R13 } \\
\hline R14 & & & & & & & & & & & \\
\hline & & Majc & award & & & $\mathrm{Me}$ & vard & & & & \\
\hline
\end{tabular}

Source: Multiple documents by MBPJ (2000-2016)

Both case studies have been selected not only due to their reputation as exemplary neighbourhood and community organization, but they are also governed under the same institutional settings. Both are resident associations (RAs) which are registered under the Registrar of Societies (RoS). RAs are not monitored by any government agency and their leaders are elected at every annual general meeting. Unlike Rukun Tetangga (RT) groups, they are not given any grants and their committees are not paid any allowances. The single distinct difference between the two CBOs is that R1 (henceforth identified as RA1) represents a higher socio-economic background as compared to R10 (henceforth identified as RA2) which is an example of a low-income neighbourhood $\mathrm{CBO}$ in Petaling Jaya. The details of the selected CBOs are set out as follows:

Table 6: Background of the selected case studies

\begin{tabular}{|c|c|c|}
\hline & RA1 & RA2 \\
\hline $\begin{array}{l}\text { Community } \\
\text { background }\end{array}$ & $\begin{array}{l}\text { Predominantly Chinese community } \\
\text { in double-storey link houses, semi- } \\
\text { detached, and bungalow houses. }\end{array}$ & $\begin{array}{l}\text { Predominantly Malay community in } \\
\text { 5-storey low-cost apartment }\end{array}$ \\
\hline Background of leader & $\begin{array}{l}\text { A retiree, previously a sportsman. } \\
\text { Appointed as a working committee } \\
\text { member for the LA } 21 \text { Working } \\
\text { Group in MBPJ pilot project phase } \\
2000-2002 \text {. }\end{array}$ & $\begin{array}{l}\text { A vocational school teacher. } \\
\text { Serving as President since the RA } \\
\text { was first established in } 2004 \text { (for } 11 \\
\text { years as well as } 4 \text { years as a } \\
\text { committee member) }\end{array}$ \\
\hline $\begin{array}{l}\text { Awards and } \\
\text { recognitions }\end{array}$ & $\begin{array}{l}\text { 2004/05 \& 2005/06 Sustainable } \\
\left.\text { Community Award ( } 2^{\text {nd }} \text { place }\right) \\
2008 / 09 \& 2010 / 11 \text { Sustainable } \\
\left.\text { Community Award ( } 1^{\text {st }} \text { place }\right) \\
2015 / 16 \\
\text { The best CBO in Community }\end{array}$ & $\begin{array}{l}2011 / 12 \& 2012 / 13 \\
\text { Sustainable Community Award ( } 1^{\text {st }} \\
\text { place) } \\
2013 / 14 \\
\text { Sustainable Community Award ( } 2^{\text {nd }} \\
\text { place) }\end{array}$ \\
\hline
\end{tabular}


Governance \& 2nd place in Youth Sustainable Initiative category
2015/16

Special Initiative Award for Culture $\&$ Community, Sustainable Community Award ( $1^{\text {st }}$ place for youth category), \& Special Jury

Award

\subsection{Analysis procedures}

As illustrated in Figure 2, in the preliminary phase, multiple documents obtained from the LA21 Unit of MBPJ were gathered by mapping various information for screening and filtering processes. Field notes were developed to distinguish the researcher's anecdotes from the contents of the documents. Content analysis was conducted to analyse the identified documents which produced coded themes.
These coded themes lead to the development of interview questions targeting the key experts. The themes also guided the selection of two case studies. Findings for the first case study were acquired through document analysis, while findings for the second case study were acquired through face-to-face interview with community leaders as a part of the contribution to document analysis. Findings from both case studies were corroborated with the experts who participated in the interviews.

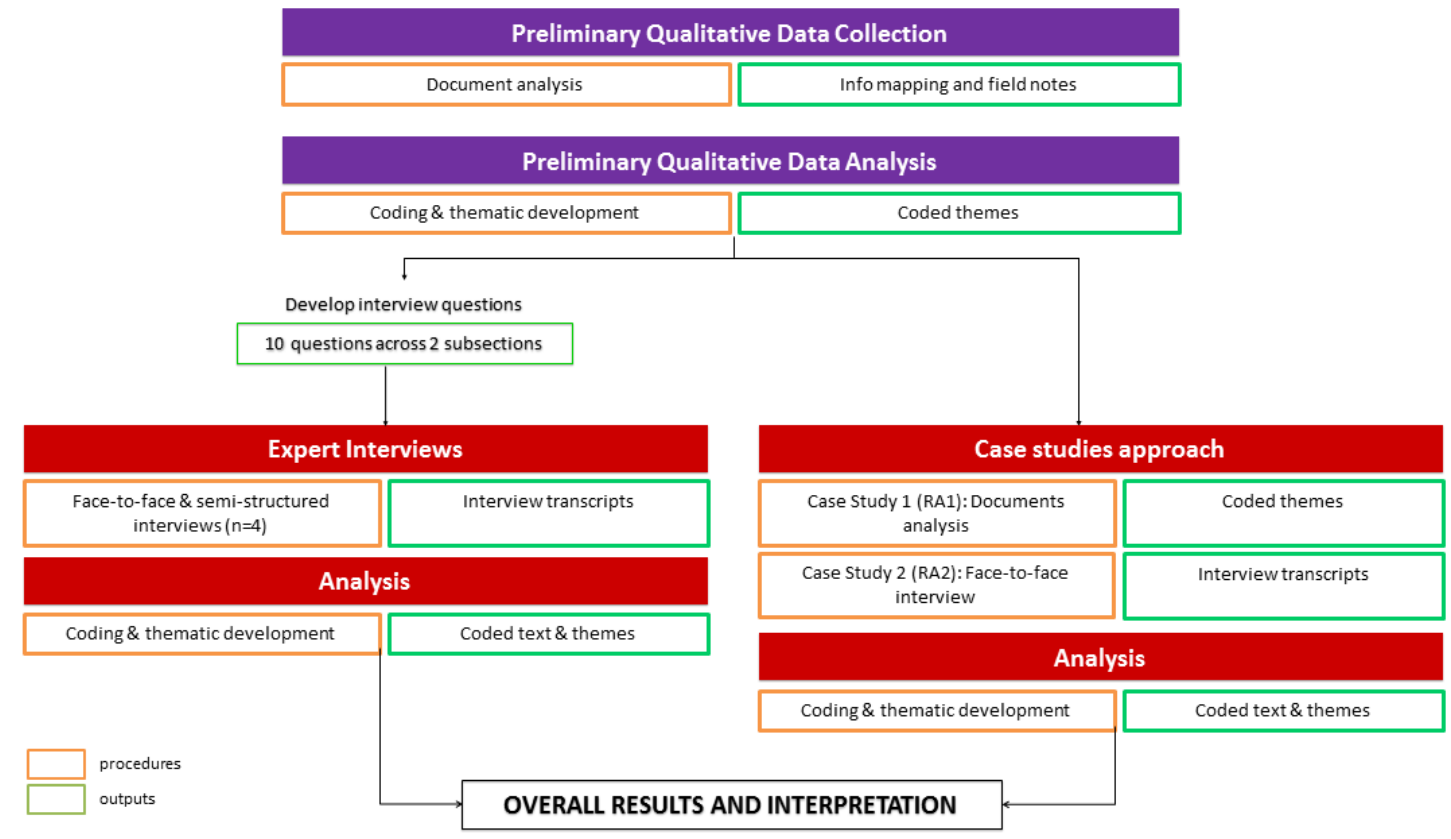

Figure 2: Data collection and analysis procedures

\section{FINDINGS AND DISCUSSIONS}

\subsection{Case study 1: RA1}

RA1 was among the earliest participants to take part in the annual Sustainable Community Award, a major LA21 program in Petaling Jaya. They are well-known for their signature initiatives namely herbal garden, rainwater harvesting system, and a recycling centre. These initiatives have earned them continuous recognition as a sustainable community since their participation in the LA21 program. RA1 persists as an exemplary CBO in Petaling Jaya by earning five major awards as a sustainable community since the inception of LA21 by MBPJ. Recently, in 2016, they were awarded the best $\mathrm{CBO}$ in community governance and they also won second place in the youth sustainable initiative category. In comparison to several CBOs that were initially committed to local sustainable initiatives but which interest then declined as time goes by, RA1 seems to have thrived all the way. Their consistent efforts towards recycling are described by Lee (2009) as follows:

Since year 2000, community recycling centre was established, and the initiative is 
still going strong. From a mere buy back centre, the recycling has developed into a collection centre in which many of the public donated money to the Residents Association's social fund. From a centre collecting the conventional types of recyclable items, it (now) accommodates other types as well such as computer, beverage cartoon, and spectacles.

RA1's active participation in sustainable initiatives at their neighbourhood level has somehow equipped them with the ability to expand their initiatives by collaborating with external agencies and authorities that can provide them with the funding, knowledge and skills which they do not possess. For instance, in partnership with a renowned computer company, an NGO, and MBPJ, RA1 together with six other CBOs in Petaling Jaya have committed to a two-year collaborative effort in computer recycling (Source: MBPJ, 2014). RA1 stepped up to another level of partnership through a sustainable initiative collaboration with an agricultural and farming company (Jonas, 2014). The urban farming initiative involves a partnership with an NGO that provides the skills and knowledge in green technology. Such collaboration allows a community to participate in farming initiatives by encouraging residents to acquire vertical planting tubs for their own residence (Lye, 2014). Through collaboration with MBPJ and the Institute of Engineers Malaysia (IEM), RA1 has become the pioneer in water conservation awareness by becoming the first $\mathrm{CBO}$ in Petaling Jaya to install a Rainwater Harvesting System at its community centre (Jayaraj, 2010). The system features a rain bank, which works as an automatic switchover to the main portable water supply tank when the rain water tank empties. Water collected from the system is used at the RA1's gardening club and for the community centre activities (Lee, 2009).

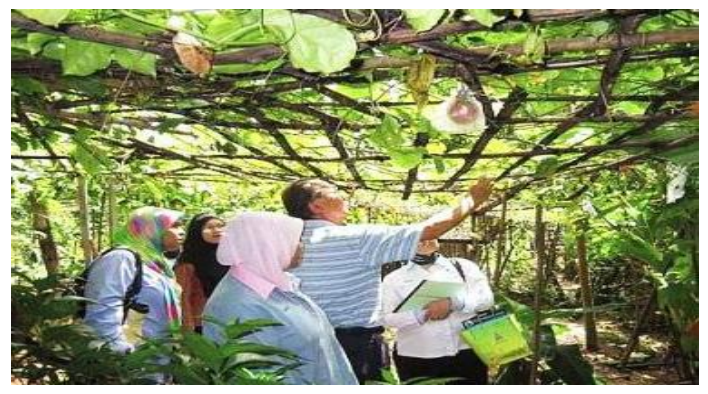

Figure 3: Visit by local authorities' personnel to RA1's herbal garden.

Source: The Star Online (accessed on July $18^{\text {th }}$, 2017).

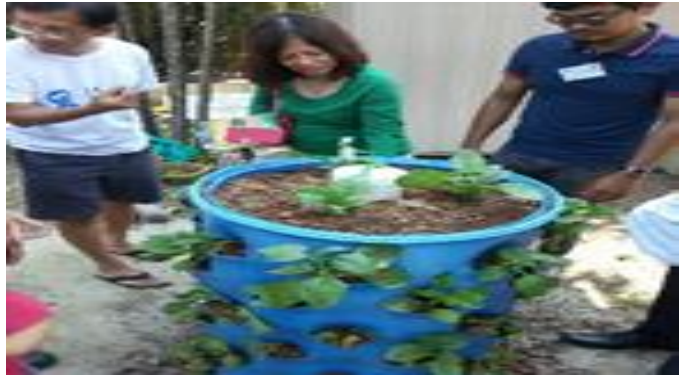

Figure 4: Residents of RA1 acquiring vertical planting tubs for their own homes.

Source: Expertise Resource Association website (accessed online on July 18 ${ }^{\text {th }}$, 2017).

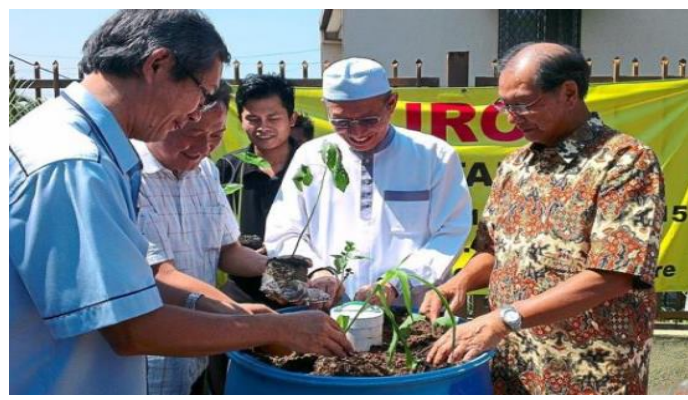

Figure 5: RA1 expanding green initiatives to include urban farming.

Source: The Star Online (accessed on July $18^{\text {th }}$, 2017).

\subsection{Case study 2: RA2}

Low-income communities have always been associated with poor waste management problems and social-related problems. As required under the Strata Management Act 757 (2013), low-cost apartments are governed by Joint Management Boards (JMBs), which is effectively the neighbourhood's local government in providing services. This poses as an additional problem as RAs are often in conflict with the JMBs. These problems, however, served as opportunities for the residents to build and develop communal trust. According to Purdue (2001), this trust may not be realised without transactional leadership displayed by the community leader. A teacher by profession, the leader of RA2 entered the platform of LA21 to mobilise his community. RA2 is encouraged by the attractive incentives provided by MBPJ. Their success can be traced back from 2010 since they first participated in a major LA21 program initiated by MBPJ. Since then, RA2 has never missed opportunities to participate in sustainable initiatives program and has thereafter earned major awards on a consistent basis. In year 2016, RA2 was awarded the most sustainable community award by MBPJ. 


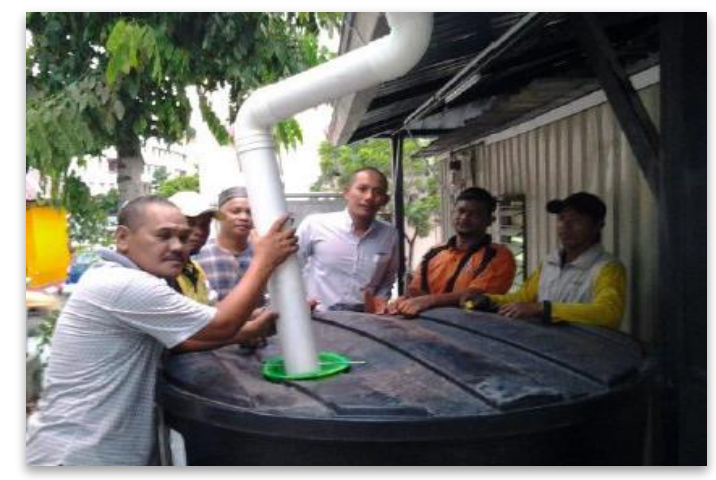

Figure 6: RA2's installation of rainwater harvesting system.

Source: MBPJ (2014).

The numerous acknowledgements they received have built up their confidence level. They have successfully broken the stereotype that poor communities cannot thrive in sustainability efforts. Through the platform of LA21, they have been exposed to networking opportunities. They attempted to learn from other successful communities and emulated RA1's Rainwater Harvesting System. In their neighbourhood, the rain bank is used predominantly for car washing. However, they do lack knowledge and skills in implementing other green initiatives. Therefore, they focused on existing capacities as they must respond to more important local needs. Their fire safety initiative has gradually increased their efficiency, whilst dengue problems led them to take the initiative to educate local residents and reduce the amount of dengue cases in their neighbourhood. Knowing the importance of sustainability initiatives, they established junior committees, under the leadership of their teenagers, to ensure that future leadership transition will be smooth. Consequently, they earned first prize for Youth Sustainable Initiative in 2016.

RA2 has entered a new phase of learning by becoming a partner in MBPJ's first smart partnership initiative in LA21. This is a collaborative effort with a well-known property developer and several educational institutions, facilitated by MBPJ in a pioneer local community project known as the i-play Park. The CBO has earned what Purdue (2001) identifies as a collaborative trust. It happens when a leader manages to perform a transformational leadership skill.

\section{Charismatic community leadership}

RA1 and RA2 have completely contrasting community profiles. While RA1 governs a middle and upper-middle income neighbourhood where most residents own landed properties, RA2 oversees a low-income neighbourhood comprising 2460 units of houses in eight blocks of 4-storeys high buildings (Source: MBPJ, 2015). These two RAs face different challenges mainly due to their contrasting socio-economic profiles. However, both CBOs are recognised as among the most successful neighbourhoods in Petaling Jaya. Although RA1 runs a relatively more matured neighbourhood which is among the earliest settlements in Petaling Jaya, RA2 on the other hand, manages a neighbourhood which is only as old as LA21 in Petaling Jaya, bringing it close to two decades of establishment.

Despite such differences, there are two major similarities identified in these CBOs. Firstly, both CBOs have been led by charismatic leaders. As observed by M-E1:

I (have) discovered that vibrant and energetic communities shared a common thing, which is the presence of strong leadership. The community is always led by a leader with calibre who is charismatic, resourceful, well connected, outspoken, engaging, able to mobilise the mass and some time is financially sound although it is not a necessity. You can see and sense the difference when meeting leaders with these qualities.

In the same vein, all experts interviewed also believe that the strongest factor influencing a CBO's continuous participation and ability to engage itself in any partnership in LA21 is charismatic community leadership. E1 synthesized community leadership in relation to partnership with MBPJ. According to him, a partnership between a $\mathrm{CBO}$ and $\mathrm{MBPJ}$ is possible with the presence of strong community leadership:

E1: ... there's the next level of cooperation where people start to work with the local authority. It's the level of cooperation which I call partnership. And that's the point where you see (a CBO leader in PJ) said: "I would like to take a leadership role in this (community initiative), I want to initiate this." MBPJ then said, "It's a good idea. In line with our Safe City Program (for instance), let's do it together". 
Based on her observations, E2 acknowledged that community leadership is translated in the form of strong cohesion and continuous learning. As extracted from her comments:

E2: It all goes out to leadership I would say...You can feel the community spirit...It translates the whole thing. They are always looking at how to improve themselves.

It is important to note that continuity of leadership is regarded by experts as a factor which affects a community's sustainability. Without smooth transition of leadership, a community may suffer from discontinuity of sustainable initiatives and this may break the communal trust which has been built. As described by Lee (2011):

I saw discontinuity of programmes in the community due to the changing of leadership. When a new leader takes over, (he'll probably) abandon a popular and sustainable initiative...I saw a community let go a recycling programme after the demise of the leader. I also felt sad about a neighbourhood losing its CCTV security scheme when its former leader left the neighbourhood.

Both RA1 and RA2 seem to have taken the time to build what Purdue (2001) identifies as communal trust. Through transactional type of leadership where leaders fulfil their obligations to their communities, both RAs have accumulated communal trust in their neighbourhood in practically different ways. As safety issues remain a constant neighbourhood problem, the RA1 leadership worked towards establishing an efficient security scheme which was initially supported by only 30 per cent of its residents before more than 80 per cent of its residents contributed to the scheme many years later (Lee, 2009). In addition, as most properties in its neighbourhood belong to retirees and senior citizens, RA1's Community Centre gives priority to the welfare of these senior citizens. Such community exhibits several indicators of liveability such as sense of inclusion (Callahan, 2007), community involvement and interaction (Howley et al., 2009; Leby \& Hashim, 2010; Lloyd et al., 2016; Wheeler, 2001), moral support from family, friends, and neighbours (Buys \& Miller, 2012), distinctive local activities (Balsas, 2004; Throsby, 2005), and neighbourhood safety (Balsas, 2004; Wheeler, 2001).
RA2, as opposed to RA1, faces challenges in improving the socio-economic wellbeing of its community members. The leader may have begun accumulating trust while serving as personnel in charge of identifying eligibility for financial aid among the urban poor living in the neighbourhood and its surroundings. Such trustbuilding continues as he provides employment opportunities for residents who have certain experiences and related background to serve in the JMB office after its committee merged with the RA's committee. In addition, sustainable initiatives implemented by RA2 mostly stem from interest or talent possessed by its residents. A well-known initiative on fire safety was established under the leadership of its residents who retired from serving as firemen in the army. They once won a merit award on entrepreneurship initiative by making profit through collective food business. These are examples of initial efforts taken to build communal trust by responding to the urgent needs of the local community through the exercise of transactional leadership (Purdue, 2001). These efforts, which provide sources of economy and bases of life, are examples of a functional environment indicator of liveability as categorised by Leby and Hashim (2010).

\subsection{Continuous community learning}

The second similarity identified in these CBOs is continuous learning. Continuous participation in LA21 programs signals continuous community learning. One of the themes that emerged from the interviews with the experts is the transformation of community behaviour within the context of participation in any sustainability programs implemented by their local authority, MBPJ. Such transformation of behaviour is a result of communicative learning (Marschke \& Sinclair, 2009). Experts interviewed were first asked on the relationship between MBPJ and the local community within the process of Local Agenda 21, since MBPJ was selected as one of the four pilot projects in the country in 2000. While the basic service provider and client relationship persists, another type of relationship has also developed. A common view amongst the interviewees was that changes were evident. A variety of perspectives were expressed on how these changes are taking place. E1 explains that changes are taking place in terms of the community's attitude towards MBPJ. An extract of the interview is presented as below: 
E1: At the most basic level, it is a clientcustomer relationship. We pay the rates; you (MBPJ) clean the roads for us. This exists in many parts of PJ; they are the sorts that really don't care. And then (secondly), there's another level of relationship where the community starts to care... They realize that cooperation is a great way to get what they want. This community asks, "Hey MBPJ, what kind of program do you have?" (But) lately, there's a next level up of cooperation where people start to work with the local authority. It is a level of cooperation which I call partnership.

These changes are translated as examples of communicative learning similar to those identified by Kilpatrick et al. (1999); Sims (2012) and Spaling et al. (2011) as they learn how to work with various levels of government and become more aware of environmental issues and the roles they play in collaborative efforts. Similarly, the comment below illustrates another observation of changes which occurred in terms of attitude towards participation. By comparing the nature of their participation when MBPJ initially held its first LA21 consultation in 2000 to the recent consultation held in 2015, he outlined that the local community have become more aware of their roles as partners to MBPJ. They have transformed from being a community that expects MBPJ to provide services effectively to a community that are willing to contribute their time and energy to work together with MBPJ.

E1: In general terms, it has improved a lot. You can see from the first (LA21) public consultation we had (in 2000), the kind of participation that we had last time was the basic client-service provider relationship. (Merely) complaints and complaints. But now you can see from the recent consultation we had (2015), there is actually a lot of contribution. And to some degree, there is some appreciation given to $M B P J$. I can see there's actually a feeling that they can work with MBPJ (looking at the participants of the 2015 workshop) ...They have expectations. That's why they stayed (throughout the whole program). They have reached the level of partnership with MBPJ. They are getting there, and they say, "We are your partners, we spend our time and you have to show us something". I think the relationship has evolved.
In the same way, a positive sign of community learning is briefly described by E2. His response in the extract below defines communicative learning in transforming their worldview of sustainability:

E2: During the first (LA21) public consultation (in 2000) when we talked about sustainability, they had no idea at all. Now, (if) you ask them, they have grasped much of the concept. It may not be 100 per cent, but it's getting there. More people have understood sustainability.

E3 provides a lengthy explanation of the changes he observed in the Petaling Jaya community. His first point touches on the development of skills and confidence of several CBO members. He also noted changes in terms of the level of environmental awareness among them. On top of these, he expresses admiration on the positive attitude of sharing knowledge and information. These changes indicate a significant amount of both instrumental and communicative learning which transformed communities participating in LA21 platform over the years.

E3: ... you can see a lot of good progress. I still remember some of the communities could not even speak (expressing their opinions). Or they don't even know how to use technology. But over the years, the communities picked up on that... That transforms the community, uplifted them in terms of confidence.

Previously, most of the communities (paid more attention) to social engagement like festival celebrations. Lately, as they slowly understand, they branched into other aspects, especially environmental initiatives. Social and safety initiatives were there. But the environment was not at all on their agenda... (Most) have started their recycling efforts. Almost everyone has done some sort of recycling. (That was not the case) 10 years ago.

Thirdly, I think now there is sharing values. Those days they are not so caring and sharing. But now you see a lot of people come forward and share with others. If you see some of them already shared with others... During the last cycle of sustainable community program, (there were about) five or six of them became mentors to the others. They also took initiative so other CBOs took part in the LA21 program. 
Continuous community learning due to charismatic community leadership may have substantially contributed to the creation of transformational leadership within the CBOs. Both RA1 and RA2 have expanded their initiatives beyond their neighbourhood level to participate in multiple stakeholder partnerships which are not common to any typical CBO. By equating transformational leaders to social entrepreneurs, Purdue (2001) recognises their vision and sense of vocation, as well as their resourcefulness in managing limited time and money. Being RAs, as opposed to Rukun Tetangga, which is another type of community organisation with annual funding allocation, they are nurtured within their operational environment to function within their means. After developing transactional leadership which earn their leaders communal trust, knowledge and skills were then acquired to develop transformational leadership and earn what Purdue (2001) defines as collaborative trust. This leadership and trust is therefore a prerequisite for a $\mathrm{CBO}$ to play a role in urban governance initiatives such as LA21, through effective partnership arrangements. Such capacity of a neighbourhood bolsters the factor of liveability through strong and established networking (Throsby, 2005).

\section{CONCLUSIONS}

This paper has highlighted LA21 as a local public 'space'. It has created and empowered the local capacities of the grassroots communities. This 'local public space', when injected with accumulated social capital elements such as trust and leadership, results in the capacity building of these grassroots communities. By time, local communities are more empowered through continuous learning in achieving livability. Both case studies have displayed cohesive and inclusive communities which are efficiently managed. A significant amount of time has been spent on learning to improve their neighbourhoods. As acknowledged by Md Dali et al. (2016), such process in achieving liveability is a continuous process.

Understanding of community leadership and learning in LA21 has brought us to consider a more dynamic approach of community participation in sustainability efforts. As opposed to the participation of exclusive members of society who have the capacities to participate in decision-making levels and public objections or consultations, community leadership and learning have significant influence in empowering local communities to participate in sustainable initiatives at their neighbourhood level. CBO members' participation in sustainable initiatives at grassroots level is a form of active participation indeed, commonly identified as informal mechanisms of participatory approach.

In an attempt to understand how CBOs participate in LA21 platform through the implementation of sustainable initiatives, it can be concluded that neighbourhoods under strong leadership are constantly aiming towards living sustainably through consistent learning. Continuous participation due to continuous charismatic leadership has caused them to keep learning. Consequently, through participation, particularly in any LA21 platform, strong attachment and sense of belonging are created, which in turn result in community liveability.

\section{ACKNOWLEDGEMENTS}

This paper forms part of a study funded by University of Malaya PPP Research Grant (PG126-2014B). It is also conducted as a part of an ongoing doctoral study sponsored by the university's Postgraduate Scholarship Scheme (SBUM).

\section{REFERENCES}

Abdul Halim, S., Salleh, H., \& Omar, M. (2011). Engaging the Local Community in Participatory Resource Management Through Learning: The Experience from Langkawi Island, Malaysia. Kajian Malaysia, 29(1), 125-139.

Andrews, R. W., Cowell, R. J. W., Downe, J. D., Martin, S. J., \& Turner, D. (2008). Supporting Effective Citizenship in Local Government: Engaging, Educating and Empowering Local Citizens. Local Government Studies, 34(4), 489-507. http://doi.org/10.1080/03003930802217462

Balsas, C. J. L. (2004). Measuring the livability of an urban centre: an exploratory study of key performance indicators. Planning Practice \& Research, 19(1), 101-110.

Barrutia, J. M., \& Echebarria, C. (2011). Explaining and measuring the embrace of Local Agenda 21s by local governments. Environment and Planning A, 43, 451-469. http://doi.org/10.1068/a43338

Bos, D. G., \& Brown, H. L. (2015). Overcoming barriers to community participation in a catchment-scale experiment: building trust and changing 
behavior. Freshwater Science, 34(3), 11691175. http://doi.org/10.1086/682421.

Bradbury, S., \& Middlemiss, L. (2015). The role of learning in sustainable communities of practice. Local Environment: The International Journal of Justice and Sustainability, 20(7), 796-810. http://doi.org/10.1080/13549839.2013.8720 91

Brandt, U. S., \& Svendsen, G. T. (2013). Is local participation always optimal for sustainable action? The costs of consensusbuilding in Local Agenda 21. Journal of Environmental Management, 129, 266-273. http://doi.org/10.1016/j.jenvman.2013.07.02 0

Brooks, R., \& Moore, A. (1997). Establishing Learning Communities for Economic Development. In Proceedings of the International Conference on Community Development Society. Athens, Georgia, USA.

Buys, L., \& Miller, E. (2012). Residential satisfaction in inner urban higher-density Brisbane, Australia: role of dwelling design, neighbourhood and neighbours. Journal of Environmental Planning and Management, 55(3), 319-338.

Callahan, K. (2007). People, Politics, Participation, and Place. Public Administration Review, 67(5), 950-954.

Dola, K., \& Mohd Noor, K. B. (2012). Managing Towards Sustainable City: Public Participation for Safety and Security. British Journal of Arts and Social Sciences, 4(116122).

Fagotto, E., \& Fung, A. (2006). Empowered participation in urban governance: The Minneapolis Neighborhood Revitalization Program. International Journal of Urban and Regional Research, 30(September), 638-655. http://doi.org/10.1111/j.14682427.2006.00685.x

Groenewald, C., \& Smith, A. (2002). Public Participation and Integrated Planning in Decentralized Local Government: A case study of democratic transition in South Africa. In P. McLaverty (Ed.), Public Participation and Innovations in Community Governance (pp. 35-62). Ashgate.

Häikiö, L. (2012). From Innovation to Convention: Legitimate Citizen Participation in Local Governance. Local Government Studies, 38(4), 415-435. http://doi.org/10.1080/03003930.2012.6982 41

Hoe, K. C., Samah, A. A., Hashim, A. H., Redzuan, M., \& Wan Jaafar, W. M. (2015).
Peranan Organisasi Berasaskan Komuniti (OBK) dalam pembangunan komuniti : Suatu pemerhatian awal. Geografia: Malaysian Journal of Society and Space, 11(3), 53-60.

Howley, P., Scott, M., \& Redmond, D. (2009). Sustainability versus liveability: an investigation of neighbourhood satisfaction. Journal of Environmental Planning and Management, 52(6), 847-864.

Irvin, R. A., \& Stansbury, J. (2004). Citizen Participation in Decision Making: Is It Worth the Effort? Public Administration Review, 64(1), 55-65.

Jayaraj, J. (2010, November). Rain water put to good use. The Star. Retrieved from http://www.thestar.com.my/news/communit y/2010/11/08/rain-water-put-to-gooduse/\#JS6Ew5cBh1ccbeQF.99

Jonas, H. (2014, March). Damansara Jaya residents' venture into vertical farming drums lauded. The Star. Retrieved from http://www.thestar.com.my/metro/communit y/2015/03/24/fostering-unity-via-urbanfarming-damansara-jaya-residents-ventureinto-vertical-farming-drumslaude/\#iZzpmpoaB3CMtSPZ.99

Kilpatrick, S., Bell, R., \& Falk, I. (1999). The Role of Group Learning in Building Social Capital. Journal of Vocational Education \& Training, 51(1), 129-144.

Krishna, A. (2003). Partnerships between local governments and community-based organizations: Exploring the scope for synergy. Public Administration and Development, 23, 361-371.

Leby, J. L., \& Hashim, A. H. (2010). Liveability Dimensions and Attributes: Their Relative Importance in the Eyes of Neighbourhood Residents. Journal of Construction in Developing Countries, 15(1), 67-91.

Lee, L. S. (2009). Community Sustainable Initiative - Damansara Jaya. Retrieved May 18, 2017, from http://sustainablepj.blogspot.my/2009/05/co mmunity-sustainable-initiative_30.html

Lee, L. S. (2011). Community Leadership. Retrieved July 18, 2017, from http://sustainablepj.blogspot.my/2011/10/co mmunity-leadership.html

Lloyd, K., Fullagar, S., \& Reid, S. (2016). Where is the "Social" in Constructions of "Liveability"? Exploring Community, Social Interaction and Social Cohesion in Changing Urban Environments. Urban Policy and Research, 34(4), 343-355.

Lye, R. (2014). Community Project - DJROA Urban Farming Launch on 14 March 2015. 
Retrieved

from

http://www.era.org.my/community-projectdjroa-urban-farming-launch-on-14-march2015/

Marschke, M., \& Sinclair, A. J. (2009). Learning for Sustainability: Participatory Resource Management in Cambodian Fishing Villages. Journal of Environmental Management, 90(1).

Md Dali, N., Abdullah, A., \& Ahmad Sarkawi, A. (2016). Liveability Planning for Cities: Within the Islamic Framework of Maqasid Al-Shari'ah. Planning Malaysia, (Special Issue), 197-208.

Md Zan, Z., \& Ngah, K. (2012). Local Agenda 21 Program Effectiveness in Seberang Perai Municipal Council, Penang, Malaysia. OIDA International Journal of Sustainable Development, 4(6), 25-30.

Md Zan, Z., Ngah, K., \& Talib, A. (2014). Sustainable Urban Community Development Through Agenda 21. Journal of Techno Social, 6(1), 1-10.

Mehta, P. (1996). Local Agenda 21: Practical Experiences and Emerging Issues from the South. Environmental Impact Assessment Review, 16(4), 309-320.

Mezirow, J. (1997). Transformative Learning: Theory to Practice, (74), 5-12.

Michels, A., \& De Graaf, L. (2010). Examining Citizen Participation: Local Participatory Policy Making and Democracy. Local Government Studies, 36(October 2014), 477-491.

http://doi.org/10.1080/03003930.2010.4941 01

Middlemiss, L. (2011). The Power of Community: How Community-Based Organizations Stimulate Sustainable Lifestyles Among Participants. Society \& Natural Resources, 24(11), 1157-1173. http://doi.org/10.1080/08941920.2010.5185 82

Mohamad, M., Silong, A. D., \& Hassan, Z. (2009). Participative and effective community leadership practice in Malaysia. Journal of Human Resource and Adult Learning, 5(1), 139-147.

participatory governance and urban environment management . The experience in Arequipa during 2003-2006. Habitat International, 35(1), 84-92. http://doi.org/10.1016/j.habitatint.2010.04.0 03

Purdue, D. (2001). Neighbourhood governance: leadership, trust and social capital. Urban Studies, 38(12), 2211-2224. http://doi.org/10.1080/00420980120087135

Razavizadeh, A. S., Majedi, H., \& Habib, F.
Mokhtar, N., \& M.Dali, M. (2015). Sustainable community initiatives: a unique partnership and participatory approach. WIT Transactions on Ecology and The Environment, 193, 725-735. http://doi.org/10.2495/SDP150611

Munro, H., Roberts, M., \& Skelcher, C. (2006). Partnership Governance and Democratic Effectiveness: Community leaders and public managers as strategic actors. In The Interpretive Practitioner: From Critique to Practice in Public Policy Analysis. The University of Birmingham.

Muro, M., \& Jeffrey, P. (2008). A critical review of the theory and application of social learning in participatory natural resource management processes. Journal of Environmental Planning and Management, 51(3), 325-344. http://doi.org/10.1080/09640560801977190

Nordin, N. A., Ngah, K., \& Zainol, R. (2012). Trust and Civic Action in Urban Planning: Evidence from Subang Jaya. Malaysian Townplan Journal, 9(1), 56.

Novy, A., \& Hammer, E. (2007). Radical innovation in the era of liberal governance. European Urban and Regional Studies, 14(3), 210-222.

Otto-zimmermann, K. (2012). From Rio to Rio +20 : the changing role of local governments in the context of current global governance. Local Environment: The International Journal of Justice and Sustainability, 17(5), 511-516. http://doi.org/10.1080/13549839.2012.6865 64

Pereira, J. J., Komoo, I., Hasan, M. N., \& Hashim, H. S. (2005). Refocusing Development Towards Sustainability - The Case of Selangor, Malaysia The Bruntland Commission articulated the concept of sustainable development as it is known today in 1987 . In this concept, equity, growth equity, integrated with elements. Malaysian Journal of Environmental Management, 6, 125-135.

Peris, J., Acebillo-baqué, M., \& Calabuig, C. (2011). Scrutinizing the link between (2016). The Role of Physical Characteristics in Enhancing Social Interaction and Use of Urban Space ( A case analysis of neighborhood center of Soltan Mir Ahmad, Kashan). Journal of Design and Built Environment, (Special Issue), 1-6.

Selman, P., \& Parker, J. (1997). Citizenship , civicness and social capital in local agenda 21. Local Environment: The International Journal of Justice and Sustainability, 2(2), 171-184. 
http://doi.org/10.1080/13549839708725522

Sims, L. (2012). Taking a Learning Approach to Community-based STrategic Environmental Assessment: Results from a Costa Rican Case Study. Impact Assessment and Project Appraisal, 30(4), 242-252.

Spaling, H., Montes, J., \& Sinclair, A. J. (2011). Best Practices for Promoting Participation and Learning for Sustainability: Lessons from Community-based Environmental Assessment in Kenya and Tanzania. Journal of Environmental Assessment Policy and Management, 13(3).

Throsby, D. (2005). Cultural heritage as financial asset in strategies for urban development and poverty alleviation. In Life in the urban landscape: International conference for Integrating urban knowledge \& practice (pp. 2-14).

Wheeler, S. M. (2001). Livable communities: Creating safe and livable neighborhoods, towns and regions in California. Berkeley. Retrieved from http://escholarship.org/uc/item/8xf2d6jg

Yuen, B., Ahmad, S., \& Chin, S. H. (2006). Malaysia. In B. Roberts \& T. Kanaley (Eds.), Urbanization and sustainability in Asia: Case studies of good practice (pp. 223-244). Asian Development Bank. 